\title{
Efektifitas Pemanfaatan Zoom Meeting dalam Meningkatkan Kinerja DKM Jami Darul Hikmah
}

\author{
Evy Priyanti ${ }^{1}$, Veti Apriana ${ }^{2}$, Raden Mohammad Riezky Pahlevi ${ }^{3}$ \\ ${ }^{1,2,3}$ Universitas Bina Sarana Informatika \\ Jl. Kramat Raya No.98, Jakarta Pusat, Indonesia \\ e-mail: ${ }^{1}$ evy.evp@bsi.ac.id, ${ }^{2}$ veti.vta@bsi.ac.id, ${ }^{3}$ r.mohammad.rrp@bsi.ac.id
}

\begin{abstract}
Abstrak
Pandemi Covid 19 yang berlangsung pada saat ini membuat pengurus DKM Jami' Darul Hikmah harus melakukan kegiatannya atau aktivitasnya secara daring menggunakan sarana media online. Media online yang dipakai untuk melakukan kegiatan/aktivitas dengan menggunakan zoom karena lebih familiar dan banyak pengguna sehingga perlu diadakan sosialisasi berupa Workshop untuk penggunaan Zoom. Kegiatan dan aktivitas yang sudah dilakukan pada saat ini tidak dapat dilakukan secara tatap muka dengan banyak orang dikarenakan masih berlangsungnya Pademi Covid 19. Akan tetapi pada saat ini para pengurus DKM Jami'Darul Hikmah, perlu ada menggunakan Zoom Meeting agar kegiatan / aktivitas menjadi lebih efektif, yang menjadi permasalahan selama ini pengurus DKM Jami'Darul Hikmah hanya menggunakan media komunikasi dengan Whatsapp sehingga menyulitkan para pengurus untuk melakukan interaksi dikarenakan terbatasnya fungsi yang ada di Whats App untuk kegiatan / aktivitas yang mengundang banyak orang seperti kegiatan pendidikan,pelatihan, pengajian umum, ceramah, memperingati Hari Besar Agama Islam. Metode pelaksanaan kegiatan Workshop ini dilaksanakan secara daring. Hasil luaran berupa peningkatan pengetahuan, keterampilan dari pengurus DKM Jami’Darul Hikmah.
\end{abstract}

\section{Kata Kunci: Covid-19, Zoom, DKM}

\begin{abstract}
The current Covid-19 pandemic has forced the Jami' Darul Hikmah Mosque DKM management to carry out their activities or activities online using online media facilities. in the form of a Workshop for the use of Zoom. Activities and activities that have been carried out at this time cannot be carried out face-to-face with many people due to the ongoing Covid-19 pandemic. However, at this time the administrators of the Jami'Darul Hikmah DKM, it is necessary to use Zoom Meetings so that activities / activities become more effective. The problem so far is that the Jami'Darul Hikmah DKM management only uses communication media with Whatsapp, making it difficult for the administrators to interact due to the limited functions available on Whats App for activities / activities that invite many people such as educational activities, training, public recitations, lectures, commemorating the Great Day of the Islamic Religion. The method of implementing this Workshop activity is carried out online. The output results are the publication of press releases of articles in local print or electronic mass media and an increase in the knowledge and skills of the Jami'Darul Hikmah DKM management.
\end{abstract}

Keywords: Covid-19;Zoom;DKM 


\section{Pendahuluan}

Masjid Jami Darul Hikmah dibangun pada tahun 1984. Masjid Darul Hikmah merupakan kategori Masjid Jami'. Masjid Jami'Darul Hikmah yang memiliki kurang lebih luas tanah 4000 meter persegi, luas bangunan $1000 \mathrm{~m}^{2}$ dengan status Tanah Wakaf. Masjid Jami' Darul Hikmah memiliki jumlah Pengurus Masjid 16 orang, jumlah Imam tetap 1 orang dan 10 Imam Jumat, jumlah jamaah > 200 orang, dengan jumlah guru pengajian 3 orang dan jumlah Khatib 8 orang, dengan lokasi yang berada di Jl. H. Terin Rt 06/03 No 30 kel. Pangkalan Jati Baru kec. Cinere kota Depok provinsi Jawa Barat dengan kode pos 16513.

Visi dari DKM Jami Darul Hikmah adalah Menjadi Masjid yang sesuai dengan tuntunan Syariat Islam dan misinya adalah menyelenggarakan program-program yang bertujuan mendekatkan diri kepada Allah,SWT, memakmurkan Masjid dengan pendidikan,pelatihan,dan Syiar Dakwah Islam yang berlandaskan Tauhid.

Kebijakan jaga jarak dan menghindari perkumpulan dimasa pandemic sangat berpengaruh terhadap kebiasaan dan rutinitas yang dijalani salah satunya pada kegiatan rapat yang ada pada DKM Masjid Jami Darul Hikmah, dimana banyak berkerumun antara anggota dan ketua yang membahas tentang perayaan hari raya seperti sholat Iedul fitri dan sholat Iedul Adha, juga pemotongan hewan kurban. Untuk itulah maka zoom meeting menjadi salah satu solusi dalam menyelesaikan permasalahan yang ada pada DKM Jami Darul Hikmah.

Zoom Meeting adalah sebuah media pembelajaran dimana video menjadi fitur utama. Pendiri aplikasi Zoom Meeting yaitu Eric Yuan yang diresmikan tahun 2011 yang kantor pusatnya berada di San Jose, California. Zoom Meeting ini tidak hanya untuk media pembelajaran berbentuk video saja tetapi dapat juga digunakan untuk perkantoran maupun pemerintahan. Platfrom zoom meeting ini ada pilihan dimana pengguna tidak dikenakan biaya atau gratis jadi bisa digunakan oleh siapapun dengan keterbatasan waktu empat puluh menit dan bisa digunakan selama 24 jam jika berbayar. Zoom Meeting memudahkan kita berkomunikasi dengan siapapun lewat video. Oleh karena itu, memang cocok digunakan sebagai media dalam memecahkan masalah selama pandemic supaya tidak berkerumun dan tetap memnuhi protokol kesehatan (Danin Haqien, 2020).

Penelitian yang berfokus pada penggunaan Aplikasi Zoom Cloud Meeting sebagai media e-learning merupakan bagian dari unsur komunikasi, salah satunya adalah pesan atau informasi yang disampaikan oleh ketua dan para anggota dapat tersampaikan dan mendapatkan umpan balik langsung dari komunikannya. Apabila terdapat komunikasi yang terjadi diantara pihak yang terlibat bisa terjalin dengan baik maka akan menghasilkan umpan balik yang baik juga atau selaras dengan tujuan dari terjalinnya komunikasi tersebut (Wulandari, 2020).

\section{Metode}

Penelitian ini merupakan penelitian dengan jenis deskriptif yang mana menjabarkan fenomena dari populasi yang diteliti yaitu DKM Jami Darul Hikmah dengan tahap awal dilakukan persiapan untuk Pelaksanaan Pengabdian Masyarakat berupa pelatihan tools-tools yang pada aplikasi zoom meeting. Setelah itu dilakukan dokumentasi untuk panitia Pengabdian Masyarakat dilanjutkan dengan pemaparan materi dan dilanjutkan dengan menampilkan link Kuesioner beserta video materi yang akan diajarkan.. Dikarenakan adanya keterbatasan dalam situasi pandemic maka proses pengabdian masyarakat dilakukan secara daring dan luring. Proses pelaksanaan secara daring dilakukan dengan Pelaksanaan dilakukan secara daring dengan Meeting ID: 82681478168 dan Passcode atau password untuk login adalah PM beserta Link untuk id zoom sebagai berikut Zoom: https://us02web.zoom.us/j/82681478168?pwd=aEFsV1EzUWcvZ01SOEQycHZmYTROdz09 
- Penyampaian materi oleh tutor sangat disambut hangat oleh para perserta. Para peserta sangat antusias dalam menyimak materi yang diajarkan karena sangat membantu semua proses yang ada didalam kegiatan-kegiatan masjid seperti rapat perayaan hari raya atau rapatrapat lainnya dimasa pandemic seperti sekarang ini.

Proses pengabdian masyarakat ini juga melibatkan mahasiswa dalam proses pengabdian masyarakat, mahasiswa yang terlibat diantaranya adalah Ranty Dwi Astuti, Maria Petrosia Wula Menge dan Muhammad Farhan.

\section{Hasil dan Pembahasan}

Pandemi covid 19 yang melanda dunia sangatlah mempengaruhi pola kehidupan manusia dan hingga 5 Oktober 2021 di Indonesia positif sebanyak 4.221.610 sembuh 4.049.449 meninggal 142.338 untuk data global di 225 negara sebanyak 235.175.106 yang terkonfirmasi dan meninggal sebanyak 4.806.841 (RI, 2021).

Beberapa kegiatan Dewan Kemakmuran Masjid salah satunya adalah menyikapi tentang kewajiban shalat jumat bagi umat lslam yang sehat dalam hal kondisi aman (zona hijau yang ditetapkan pemerintah) dari bahaya penularan COVID-19, dengan dasar Al-Qurán surat Al-Jumuah ayat 9, Sunnah, dan ijma 'ulama. Maka pengurus dewan kemakmuran masjid wajib menyelenggaran shalat jumat dan shalat fardhu berjamaah shalat sunnah rawatib, shalat taraweh dan led di masjid atau tempat umum lainnya, serta menghadiri pengajian umum dan majelis taklim.dan ibadah lainnya di masjid bagi umat lslam yang sehat (Abdullah, 2020).

Dampak Fatwa MUI No. 14 tahun 2020 Tentang Penyelenggaraan Ibadah Dalam Situasi Terjadi Wabah Covid 19 terhadap sikap masyarakat umat lslam. Dengan adanya Fatwa MUI nomor 14/2020, timbul berbagai macam reaksi pro dan kontra sikap masyarakat umat lslam, di antaranya (Abdullah, 2020) :

a. Menutup masjid dari berbagai kegiatan ibadah wajib dan sunnah.

b. Masjid tetap buka dari berbagai kegiatan ibadah wajib dan sunnah.

c. Masjid jami' tidak mengadakan shalat jumat tapi melaksanakan shalat dzuhur di hari jumat, dan shalat fardhu lainnya secara berjamaah.

d. Masjid jami' tidak mengadakan shalat jumat tapi melaksanakan shalat teraweh.

e. Masjid jami' tidak mengadakan shalat jumat dan tidak melaksanakan shalat teraweh.

f. Adanya pengurus dan jamaah musholla yang mengadakan sholat jumat dadakan karena merasa sehat dan merasa wajib melaksanakan karena berada pada zona hijau dan wilayahnya sudah diisolasi sehingga tidak ada orang luar yang datang untuk sholat jumat.

g. Adanya musholla dan majlis ta'lim yang mengadakan shalat teraweh karena masjid di sekitarnya tidak mengadakan shalat teraweh.

h. Shaff dalam shalat berjamaah sedikit renggang dan tanpa jabat tangan usai shalat. Serta penutup do'a tanpa mengusap muka dengan dua tangan.

i. Sesuai anjuran pemerintah untuk shalat di rumah, maka ada rumah yang agak besar mengadakan shalat teraweh dan tetangganya ikut bergabung shalat, karena rumahnya kecil tidak bisa digunakan untuk shalat teraweh.

j. Timbulnya sikap kontroversi di kalangan Ulama dalam menanggapi pendapat ulama yang berpendapat tidak perlu shalat jumat di masjid lalu diganti shalat dzuhur di rumah dan pendapat ulama yang tetap melaksanakan shalat jamaah jumat di masjid.

Pengetahuan dan informasi yang ada di masyarkat mengenai cara penularan COVID-

19 sebagian besar dengan penularan COVID-19 melalui udara dan sebagian kecil dengan cara penularan COVID-19 melalui bersentuhan. Hal ini tidak sesuai dengan yang dikemukakan oleh WHO tahun 2020, dimana disebutkan bahwa COVID-19 dapat menyebar 
melalui percikan-percikan dari hidung atau mulut yang keluar saat orang yang terinfeksi COVID-19 batuk, bersin atau berbicara. Percikan-percikan ini relative berat, perjalanannya tidak jauh dan jatuh ke tanah dengan cepat. Orang yang terinfeksi COVID-19 jika menghirup percikan orang yang terinfeksi virus ini (Nurul Hidayah Nasution, 2021).

Peran Dewan Kemakmuran Masjid sangatlah penting dalam pengelolaan seluruh kegiatan masjid, misalkan pada perayaan kurban dimana perlu adanya persiapan tanpa adanya kerumunan dan tetap mematuhi protocol Kesehatan. Peran Dewan Kemakmuran Masjid (DKM) sangat penting dalam mengedukasi masyarakat dalam kegiatan perayaan seperti kurban supaya perayaan dapat berjalan aman dan nyaman sesuai dengan anjuran pemerintah (Ridi Arif, 2020).

Keberhasilan proses daring model satu arah dan dua arah, salah satunya ditentukan oleh pemanfaat teknologi penyedia layanan interaksi antara ketua dan anggota. Sarana yang menunjang interaksi tersebut dalam penyampaian pendapat daring banyak disediakan oleh platform-platform digital dengan berbagai kelengkapan yang berbeda sesuai dengan tujuan interaksi yang ingin dicapai (Muhamad Hasbi Assidiqi, 2020).

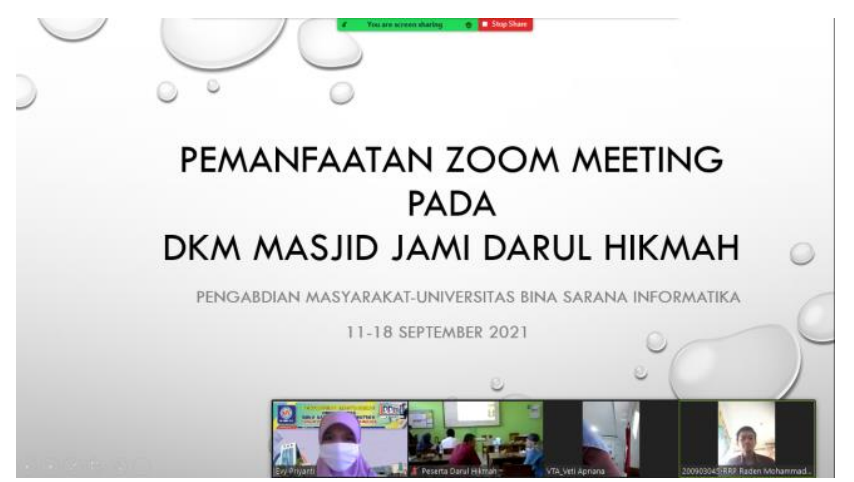

Gambar 1 Pengenalan Zoom Meeting kepada DKM

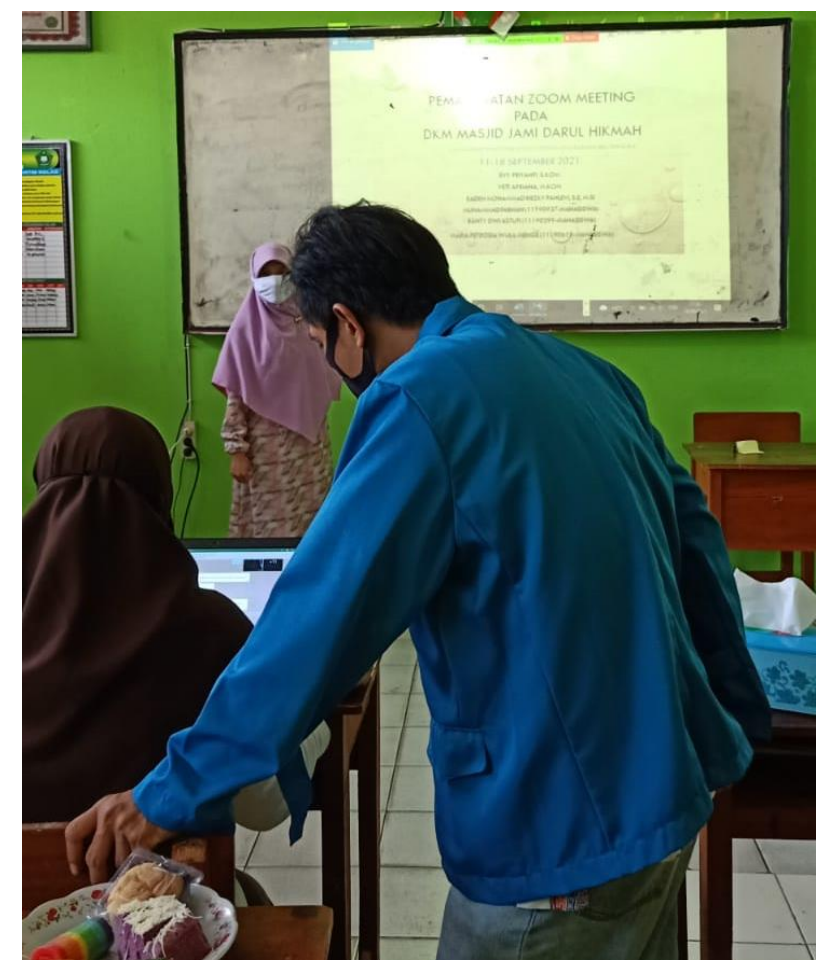

Gambar 2. Perwakilan dari Mahasiswa dan Dosen 


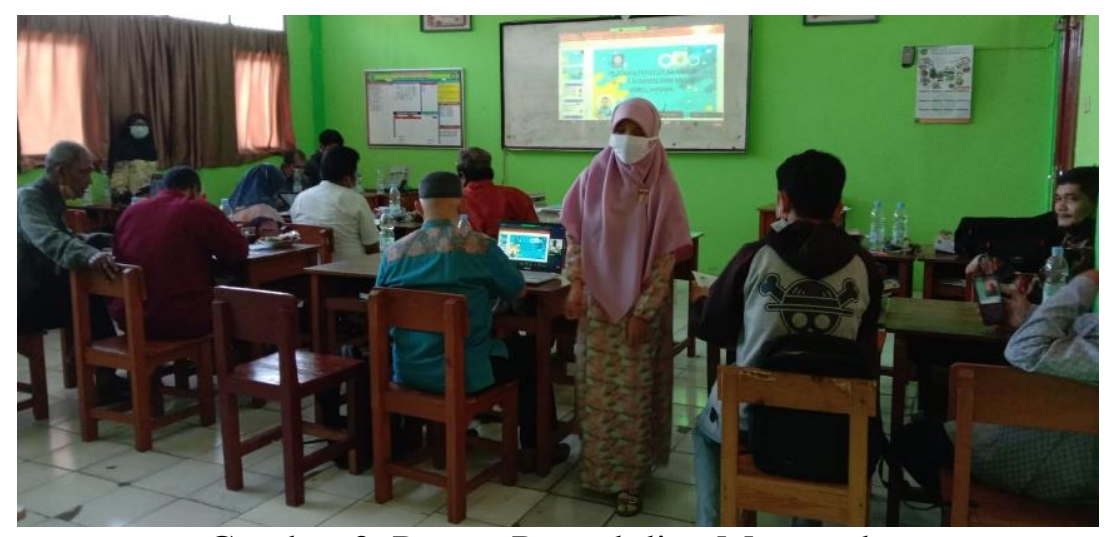

Gambar 3. Proses Pengabdian Masyarakat

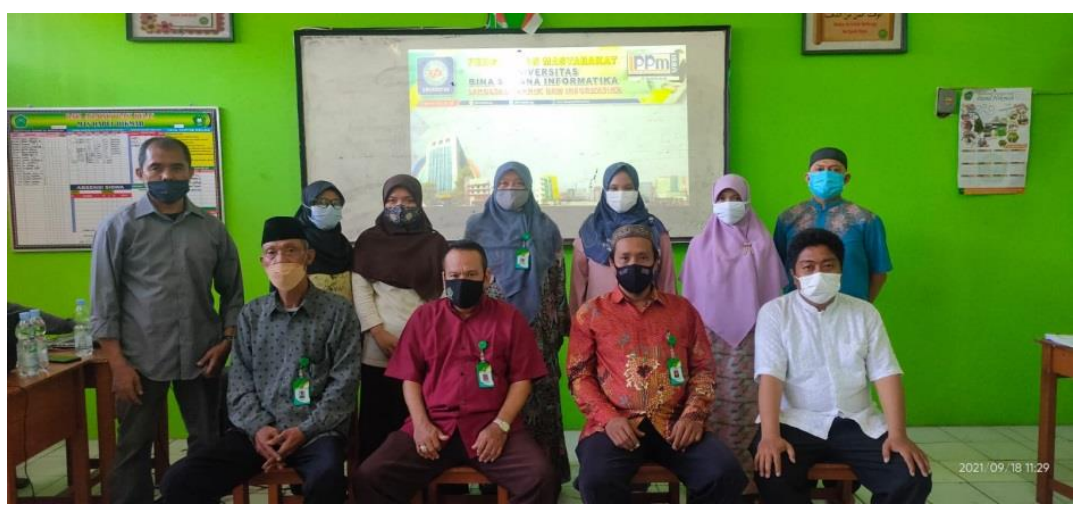

Gambar 4. Foto Bersama Mitra

Salah satu platform dalam menangani masalah yang ada selama pandemic adalah dengan cara rapat secara daring menggunakan Zoom cloud meeting, agar semua ageda DKM Jami Darul Hikmah dapat tetap berjalan dan tetap mamatuhi protokol kesehatan yang berlaku saat pandemic Covid 19 ini. Pemaparan materi yang disampaikan oleh Tim Tutor sangat membantu DKM Jami Darul Hikmah dalam menyelesaikan masalah yang selama pandemic Covid 19 ini menjadi hambatan dalam penyelenggaraan proses kegiatan-kegiatan yang ada didalam Masjid Jami Darul Hikmah.

Target luaran adalah target yang diharapkan dapat tercapai dari kegiatan pengabdian masyarakat ini:

a. Terlaksananya kegiatan pengabdian masyarakat ini dengan suasana yang kondusif.

b. Peningkatan kemampuan peserta dalam memahami penggunaan tools-tools yang ada pada aplikasi zoom meeting.

c. Dapat membantu semua proses yang ada didalam kegiatan-kegiatan masjid seperti rapat perayaan hari raya atau rapat-rapat lainnya dimasa pandemic seperti sekarang ini.

\section{Kesimpulan}

Kesimpulan yang didapatkan setelah melakukan pengabdian pada DKM Jami Darul Hikmah, diantaranya :

1. Para peserta sangat antusias dalam mengikuti kegiatan pelatihan mengenai zoom meeting ini tentunya dalam menyimak materi yang diajarkan karena sangat membantu semua proses yang ada didalam kegiatan-kegiatan masjid seperti rapat perayaan hari raya atau rapat-rapat lainnya dimasa pandemic seperti sekarang ini. 
2. Adanya peningkatan kemampuan peserta dalam memahami penggunaan tools-tools yang ada pada aplikasi zoom meeting serta menambah keterampilan dari pengurus DKM Jami’Darul Hikmah.

3. Mengajak muslim untuk menjadi lebih baik dalam segala hal

4. Dewan Kemakmuran Masjid (DKM) adalah masyarakat yang bertugas dalam menjaga kemakmuran lingkungan masjid, baik fisik dan bangunan masjid, maupun kegiatan ibadah di dalamnya.

5. Masjid dimana tempat suci yang hanya dihadiri oleh banyak orang yang sudah bersuci lebih dahulu sebelum masuk masjid. COVID 19 adalah Novel Coronavirus desesse (2019$\mathrm{nCoV}$ ), adalah virus baru penyebab penyakit saluran pernafasan. Novel Coronavirus desesse merupakan penyakit menular yang disebabkan oleh Corona virus, termasuk keluarga besar dengan virus penyebab SARS dan MERS. Covid-19 yang ditemukan pertama kali pada tahun 2019 dan berasal dari negara China. ketika orang yang terkena atau terpapar maka wajib menjaga dan mengisolasi dirinya dan keluarga yang terpapar agar tidak terjadi penularan pada orang lain.

\section{Daftar Pustaka}

Abdullah, F. (2020). Strategi Dakwah Dewan Kemakmuran Masjid (DKM) Dalam Menyikapi Covid-19 . Jurnal Studi Agama dan Pemikiran Islam Al-Risalah, 71-91.

Danin Haqien, A. A. (2020). Pemanfaatan Zoom Meeting Untuk Proses Pembelajaran Pada Masa Pandemi Covid-19. SAP (Susunan Artikel Pendidikan), 51-56.

Muhamad Hasbi Assidiqi, W. S. (2020). Pemanfaatan Platform Digital di Masa Pandemi Covid-19. Seminar Nasional Pascasarjana Unines (pp. 298-303). Semarang: Universitas Negeri Semarang.

Nurul Hidayah Nasution, A. H. (2021). Gambaran Pengetahuan Masyarakat Tentang Pencegahan Covid-19 di Kecamatan Padangsidimpuan Batunadua kota Padangsidimpuan. Jurnal Kesehatan Ilmiah Indonesia, 107-114.

RI, S. T. (2021, Oktober 2021). Beranda. Retrieved from Data Sebaran: https://covid19.go.id/

Ridi Arif, A. W. (2020). Peningkatan Peran Dewan Kemakmuran Masjid sebagai Fungsi Edukasi dalam Pelaksanaan Kurban di Tengah Pandemi Covid-19. Agrokreatif, 67-75.

Wulandari, R. E. (2020). Pemanfaatan Aplikasi Zoom Cloud Meeting Sebagai Media ELearning dalam Mencapai Pemahaman Mahasiswa ditengah Pandemi Covid 19. Jurnal Common, 171-190. 